\section{International Scientific Journal Theoretical \& Applied Science}

\author{
p-ISSN: 2308-4944 (print) e-ISSN: 2409-0085 (online) \\ Year: 2018 Issue: 09 Volume: 65
}

Published: $24.09 .2018 \quad$ http://T-Science.org
Amanay Tursunbaevna Akmatova

Candidate of Law, acting Associate Professor of

Department of theory and history of state and law of Osh state law institute

SECTION 32. Jurisprudence.

\title{
HYDROENERGY RESOURCES OF THE KIRGIS SOVIET SOCIALIST REPUBLIC ON THE EXAMPLE OF THE OSH REGION: HISTORY AND PROSPECTS
}

Abstract: Hydropower resources are the strategic potential of the Kyrgyz Republic. Rational and effective use depends on the prospects for the development of domestic industry and the role and place of the country in the global economic system. Research and study of experience in the development of hydro resources, in particular the construction of reservoirs, are necessary for solving the tasks of the national development of the Kyrgyz Republic. All this contributes to creating conditions for industrial progress in the Central Asian region.

Key words: hydropower, reservoir, protection, water, resource, perspective, industry.

Language: Russian

Citation: Akmatova AT (2018) HYDROENERGY RESOURCES OF THE KIRGIS SOVIET SOCIALIST REPUBLIC ON THE EXAMPLE OF THE OSH REGION: HISTORY AND PROSPECTS. ISJ Theoretical \& Applied Science, 09 (65): 182-185.

Soi: http://s-0-i.org/1.1/TAS-09-65-33 Doi: crossef https://dx.doi.org/10.15863/TAS.2018.09.65.33

\section{ГИДРОЭНЕРГЕТИЧЕСКИЕ РЕСУРСЫ КИРГИЗСКОЙ СОВЕТСКОЙ СОЦИАЛИСТИЧЕСКОЙ РЕСПУБЛИКИ НА ПРИМЕРЕ ОШСКОЙ ОБЛАСТИ: ИСТОРИЯ И ПЕРСПЕКТИВЫ}

Аннотация: Гидроэнергетические ресурсы это стратегический потенциал Кыргызской Республики. Рациональное и эффективное использование зависит от перспектив развития отечественной промышленности и роли и места страны в глобальной экономической системе. Исследование и изучение опьта освоения гидроресурсов, в частности строительство водохранилищ, необходимь для решения задач национального развития Кыргызской Республики. Все это способствует созданию условий для промышленного прогресса в Среднеазиатском регионе.

Ключевые слова: гидроэнергетика, водохранилище, охрана, вода, ресурс, перспектива, промыциенность.

\section{Introduction}

Советская Социалистическая Киргизия располагала огромными гидроэнергетическими ресурсами. По гидроэнергетическим ресурсам Киргизия в составе СССР занимала третье место, после РСФСТ и ТССР.

Экономико-хозяйственное значение гидроэнергетического строительства и развитие гидроэнергетики является основой промышленности Кыргызской Республики.

Гидроэлектростанции центральное место в национальной энергосистеме Кыргызской Республики. «Важнейшей экономической особенностью гидроэнергетических ресурсов является возобновляемость, не требующая в дальнейшем дополнительных капиталовложений, в результате чего электроэнергия, вырабатываемая на ГЭС, в несколько раз дешевле электроэнергии, получаемой на тепловых электростанциях» [2].

Гидроэнергетика независимой и суверенной Кыргызской Республики является необходимой базой для развития промышленности.

\section{Materials and Methods}

Ошская область самая крупная административная единица Кыргызской Республики, занимает важное положение в социально-экономической жизни страны и обладает промышленным потенциалом. 
Научное исследование гидроэнергетических ресурсов Ошской области было проведено в 1910 г. - 1915г. экспедицией инженера Н.Н. Епанчина [8].

В 1913 году вступила в строй оросительная система первая ГЭС, мощностью 55 кBm на арыке Як-Калик Ак-Бууринской.

В следующем 1914 году была построена вторая Ошская ГЭС, мощностью 65 кBm.

В 1929 году ГЭС ввелась в эксплуатацию в селе Уч - Коргон, мощность составляла $28 \kappa \mathrm{Bm}$.

В 1933 году ГЭС ввелась в эксплуатацию в селе Акчи-Кара-Суу, мощность 18 кBm.

Вторая Ферганская экспедиция проводила гидроэнергетическое обследование рек Ошской области в 1934 году. По материалам научных исследований Среднеазиатский отдел (САО) института «Гидропроект» составил в 1935 году гидроэнергетическую схему использования гидроэнергетических ресурсов юга Киргизской CCP.

Более крупная ГЭС стала действовать в 1936 году на реке Ак-Буура [10], вблизи города Ош. Мощность первого агрегата составляла 600 $\kappa B m$.

В 1939 году была введена в эксплуатацию первая сельская ГЭС в селе Базар - Коргон с мощностью 57,5кBт., а в 1940 году - вторая сельская ГЭС в селе Ноокат с мощностью 90 $\kappa B m$.

За годы Великой Отечественной войны был построен ряд сельских ГЭС небольшой мощности. В начале 1941 года было завершено строительство двух ГЭС: в селе Караван (75 кВт.) и в селе Куриаб (105 кВт.). В 1943 году для электроснабжения Ошского шелкокомбината была построена ГЭС с мощңностью 500 кВт.

Строчтельство сельских ГЭС широко развернулось в послевоенный период. В 19472. 1948 г. в колхозах и совхозах были введены в эксплуатаџию двенадцать (12) ГЭС. Начиналось сооружение межколхозных и государственных сельских ГЭС. В 1950 году была введена в строй Араванская ГЭС (544 кВт.), в 1951году Узгенская ГЭС (352 кBm.)

В 1947 г. - 1951 г. работу по подсчёту гидроэнергетических ресурсов Советского Союза, в т. ч. и Ошской области, выполнил институт «Гидроэнергопроект».

B последуюшие годы начинают действовать более крупные ГЭС, в 1949 году Джалал-Абадская ГЭС, мошиностью 512 кBm.

В 1956 году Ошская ГЭС №5 мощность составляла $1020 \mathrm{\kappa Bm.}$

В 1958 году ГЭС «1 Мая» мощностью 1000 кВт. и Моюнская ГЭС, мощностью 1300 кВт.

Через несколько лет в 1957г. - 1958г. уточнением данных занимался Институт водного хозяйства и энергетики Академии Наук Киргизской СCP. Потенциальные запасы гидроэнергетических ресурсов были определены в 35 млн. $\kappa B m$ по мощности и 30,85 млрд. $\kappa B m-\kappa$ по энергии [1].

По данным САО «Гидропроекта», на реках юга Киргизской ССР возможно было сооружение девяносто семь (97) ГЭС мощностью 966 тыс. $\kappa B m$ и среднегодовой выработкой электроэнергии 5,5 млрд. кBm-ч.

На Ои-Кара-Суйской ГЭС в 1961 году был установлен второй гидроагрегат мощчностью $400 \kappa \mathrm{Bm}$.

Первые попытки использовать богатейшие запасы гидроэнергии относятся к началу второго десятилетия XX века. «На строительство Токтогульского, Курпсайского, ТашКумырского, Шамалды-Сайского и УчКурганского гидроэнергетических и ирригационных узлов было затрачено 900 млн. рублей из союзного бюджета» [3].

Были построены также водохранилища, как Андижанское, Папанское, Киркидонское, Касансайское, Кировское и Орто-Токойское. Общий объём воды всех вышеназванных крупных ирригационных сооружений составляет 22, 978 куб. км.

Папанское водохранилище на реке Ак-Буура было построено в 1980 году по проекту Среднеазиатского

отделения Гидропроекта (г.Ташкент). Папанское водохранилище расположено в 20 км южнее города Оша. Площадь зеркала воды при полном наполнении составляет 710 га. Сооружение способно выдержать землетрясение силой в 9 баллов. «Папанский гидроузел построен на реке Ак-Буура на 40 млн. рублей (по ценам 1989 года)» [3].

Основным назначением Папанского водохранилища является регулирование стока реки для ирригации земель на юге Кыргызской Республики, на прилегающей территории Узбекистана (общая площадь орошаемых земель 35,9 тысяч га, в том числе в Кыргызской Республики 28,2 тысячи га, в Республики Узбекистан - 7,7 тысяч га), а также для питьевого водоснабжения города Ош.

В 02.06.1976 году первый секретарь Ошского областного комитета Компартии Коммунистической Партии Киргизии Султан Ибраимович Ибраимов [6] написал Докладную Записку Министру Энергетики и Электрофикаџии Союза ССР Непорожному П.С. [5], где было отмечено «Оиский областной комитет Компартии Киргизии придает большое значение вводу в эксплуатацию Папанского водохранилища поддерживая инициативу коллектива «Нарынгидроэнергострой» о досрочном вводе первой очереди Курпсайской ГЭС в 1980 году и убедительно просит оказать помощзь» [4]. 
В Докладной Записке было отмечено, что у коллектива «Нарынгидроэнергострой» сложилась крайне сложная обстановка в связи с завершением работ по Токтогульскому гидроузлу и необходимостью одновременно освоить строительные площадки в створе Курпсайской ГЭС и Папанской плотины.

«На строительство Курпсайской ГЭС и Папанского водохранилища необходимо было выполнить объём земляных работ 2,5 млн.м ${ }^{3}$. Выполнение этих работ обеспечило бы перекрытие реки Нарын в створе Курпсайской ГЭС в IV квартале 1977 года и завершение строительства стройбазы Папанского гидроузла в 1977 года. Для успешного решения этой проблемы строительному управлению «Нарынгидроэнергострой» необходимо дополнительно выделить 10 бульдозеров марки С -100 и С-130, три экскаватора с емкостью ковша 1,0 $\mathrm{m}^{3}$ и 1000 тонн металлопроката на второе полугодие 1976 года» [4, с. 112].

Строительство Папанского водохранилища на реке Ак - Буура было начато в 1976 году. Технический проект Папанского водохранилища был утвержден в конце 1975 года, к составлению рабочих чертежей проектная организация «Средагидропроект» приступила только с января 1976 года.

16 июля 1976 года в ЦК КП Киргизии Совет Министров Киргизской ССР поступило письменное указание за подписями Первого секретаря Ошского обкома КП Киргизии С.Ибраимова и Председателя Ошского облисполкома Т.Кошоева [7] где было указано, что «В связи с большим отставанием в выдаче рабочих чертежей для строительства в 1976 году и необходимостью выдать проектно - сметную документацию для строительно- монтажных работ 1976г - 1977 г. и на 1978 г. выделенных на проектные работы не хватало в размере 255 тыс. рублей. Для обеспечения выпуска проектно сметной документации по строительству Папанского водохранилища Ошский обком КП Киргизии и областной исполком просит выдать дополнительный лимит и финансирование на проектно - изыскательные работы на 1976 г ещё 45 тыс. рублей» [4].

Согласно распоряжению Совета Министров Киргизской № $280-$ Р от 17 августа 1973 года строительство ЛЭП - 35 кв. Ош- Папан было поручено Главному производственному управлению энергетики и электрификации Киргизской ССР.

$$
\text { «Просим }
$$
выделить

тресту

«Киргизэлектросетьстрой» лимит на окончание строительства ЛЭП - 35 кв. в сумме 236 тыс. рублей и потребовать от Главного Киргизской ССР окончании строительства ЛЭП к 1 октября 1975 года» [9].
На строительство Папанского гидроузла предстояло выполнение большого объема земляных планировочных работ, для чего потребовалось привлечение дополнительного количества землеройной техники.

«Просим обязать Министерство мелиорации и водного хозяйства Киргизской ССР выдать с июля до конца 1976 года управлению «Нарынгидроэнергострой» два бульдозера марки C-100. Учитывая, что на зоны затопления Папанского водохранилища необходимо переселять население, просим ходатайствовать по распространению на переселение население положения, предусмотренного в распоряжение Совета Министерства СССР от 28 августа 1968 года № 1805-P «О подготовке лома водохранилища Токтогульской ГЭС» [4].

Строительство жилых домов в городе Ош для работающих на строительстве Папанского водохранилища входило в сметно-финансовый расчет водохранилища, где генеральным подрядчиком выступало управление «Нарынгидроэнергострой». Это управление являлось специализированным по строительству гидроэнергетических объектов и не имело в городе Ош производственной базы по строительству жилых домов, а также были чрезвычайно загружены по строительству гидроэнергетических объектов.

Первый секретарь Ошского областного комитета Компартии Коммунистической Партии Киргизии Султан Ибраимович Ибраимов и Председатель Ошского облисполкома Темирбек Кудайбергенович Кошоев в Докладной Записке отметили «Просим на 1977 год определить генеральным подрядчиком по строительству жилья в городе Ош для строителей Папанского водохранилища Министерство строительства Киргизской ССР и предусмотреть, начиная с января 1977 года лимиты подрядных работ на эти цели» [4].

Генеральным подрядчиком по строительству Папанского водохранилища определено управление строительства «Нарынгидроэнергострой». Н Начальником управления строительства «Нарынгидроэнергострой был Серый Зосим Львович [5], секретарь парткома Чынгышов Турсунбек Чынгышевич [7]. Объем строительномонтажных работ составлял 2 миллиона рублей.

Роль и место Папанского водохранилища трудно переоценить в развитии комплексного использования водных ресурсов Ошской области. Строительство Папанского водохранилища было завершено в 1980 году. Объём составил 260 млн. $\mathrm{M}^{3}$, полезный объём составил 240 млн. м $^{3}$ Папанское водохранилище стал результатом научной инженерной мысли, внедрения 


\begin{tabular}{|c|c|c|c|c|c|c|}
\hline Impact Factor: & $\begin{array}{l}\text { ISRA (India) } \\
\text { ISI (Dubai, UAE } \\
\text { GIF (Australia) } \\
\text { JIF }\end{array}$ & $\begin{array}{l}=1.344 \\
=0.829 \\
=0.564 \\
=1.500\end{array}$ & $\begin{array}{l}\text { SIS (USA) } \\
\text { PИНЦ (Russia) } \\
\text { ESJI (KZ) } \\
\text { SJIF (Morocco) }\end{array}$ & $\begin{array}{l}=0.912 \\
=0.156 \\
=4.102 \\
=\mathbf{5 . 6 6 7}\end{array}$ & $\begin{array}{l}\text { ICV (Poland) } \\
\text { PIF (India) } \\
\text { IBI (India) }\end{array}$ & $\begin{array}{l}=6.630 \\
=1.940 \\
=4.260\end{array}$ \\
\hline
\end{tabular}

технических разработок и результатом работы интернационального коллектива строителей.

\section{Conclusion}

Реализация огромного потенциала Папанского водохранилища послужило развитию сельскохозяйственного хозяйства и регуляции орошения плодородных земель не только Киргизии, но и Узбекистана.

Развитие гидроэнергетики, строительство гидроузлов является обязательным условием сохранения промышленного потенциала Кыргызской Республики.
В перспективе гидроузлы становятся инструментами регулирования водонакопления, водопотребления и водоснабжения Средней Азии и организации сельскохозяйственных работ в Ферганской долине.

Особо надо отметить, что для Кыргызской Республики поддержание в рабочем состоянии существующего Папанского гидросооружения и продолжение гидроэнергетического строительства имеет особое значение.

\section{References:}

1. Belyakov Yu.P. (2018) Pervyie uchenyie: gidrologi, gidrotehniki i gidro-energetiki Kyirgyizstana. http:://www.literatura.kg/articles/

2. Medvedev A. (2018) Gidroenergetika Kyirgyizstana kak osnova stanovleniya promyishlennosti http://www.centrasia.ru/news A.php?st $=1432804020$.

3. Usubaliev T.U. (1998) Voda - dorozhe zlata. Vodnyie resursyi Kyirgyizstana - eto ego natsionalnoe bogatstvo. Bishkek 1998, -p. 13.

4. (1970) Partiynyiy Arhiv Oshskogo OK KP Kirgizii Fond 2 Opis \# 106 Delo \#8, str 106.

5. (1970) Sovetskiy Soyuz. Kirgiziya. Izdatelstvo «Myisl» Moskva 1970.
6. (1982) Kirgizskaya Sovetskaya Sotsialisticheskaya Respublika. Entsiklopediya. Frunze $1982 \mathrm{~g}$.

7. (1987) Oshskaya oblast. Entsiklopediya. Frunze $1987 \mathrm{~g}$.

8. Mamatkanov D.M., Bazhanova L.V., Romanovskiy V.V. (2006) Vodnyie resursyi Kyirgyizstana na sovremennom etape.Bishkek: Ilim, 2006.-276 p.

9. (1982) Gidroenergetika i kompleksnoe ispolzovanie vodnyih resursov SSSR / Pod red. P.S. Neporozhnego. - 2-e izd., pererab. i dop. M.: Energoizdat, 1982. -520 p.

10. Kaminskiy I.Ya. (2018) Gidroenergeticheskie resursyi Kirgizskoy ASSR i ih osvoenie. 